\title{
Sequence and gene expression of chloroquine resistance transporter (pfcrt) in the association of in vitro drugs resistance of Plasmodium falciparum
}

\author{
Wanna Chaijaroenkul ${ }^{1 \dagger}$, Stephen A Ward ${ }^{2 \dagger}$, Mathirut Mungthin ${ }^{3+}$, David Johnson ${ }^{2+}$, Andrew Owen ${ }^{4+}$, \\ Patrick G Bray ${ }^{2}$, Kesara Na-Bangchang ${ }^{1 *}$
}

\begin{abstract}
Background: Plasmodium falciparum chloroquine resistance (CQR) transporter protein (PfCRT) is known to be the important key of CQR. Recent studies have definitively demonstrated a link between mutations in the gene pfcrt and resistance to chloroquine in P. falciparum. Although these mutations are predictive of chloroquine resistance, they are not quantitatively predictive of the degree of resistance.

Methods: In this study, a total of 95 recently adapted P. falciparum isolates from Thailand were included in the analysis. Parasites were characterized for their drug susceptibility phenotypes and genotypes with respect to pfcrt. From the original 95 isolates, 20 were selected for complete pfcrt sequence analysis.

Results: Almost all of the parasites characterized carried the previously reported mutations K76T, A220S, Q271E, N326S, I356T and R371I. On complete sequencing, isolates were identified with novel mutations at K76A and E198K. There was a suggestion that parasites carrying E198K were less resistant than those that did not. In addition, pfcrt and pfmdr1 gene expression were investigated by real-time PCR. No relationship between the expression level of either of these genes and response to drug was observed.
\end{abstract}

Conclusion: Data from the present study suggest that other genes must contribute to the degree of resistance once the resistance phenotype is established through mutations in pfcrt.

\section{Background}

Malaria, especially that caused by Plasmodium falciparum, is a serious health problem in many tropical countries and this situation is made worse as a consequence of drug resistance. The 4-aminoquinoline chloroquine (CQ) was introduced in the 1940's as a cheap and effective treatment for malaria. Chloroquine-resistant (CQR) parasites were first reported in the late 1950s from South-East Asia and South-America. Since those early reports, CQR P. falciparum has spread throughout the malaria endemic world. In addition, in some areas such as the Thai-Myanmar and the ThaiCambodian borders, parasite populations resistant to most available drugs have evolved. These parasites

\footnotetext{
* Correspondence: kesaratmu@yahoo.com

+ Contributed equally

${ }^{1}$ Faculty of Allied Health Sciences, Thammasat University, Rangsit,

Patumthani 12120, Thailand

Full list of author information is available at the end of the article
}

have been referred to as multidrug-resistant (MDR) P. falciparum [1].

Reduced dug accumulation is a phenotypic feature of CQR which can be partially reversed by the calcium channel blocker verapamil, an agent that also reverses chloroquine resistance [2-5]. Two genes have been linked with this phenotype namely $p f m d r 1$ and pfcrt. The $p f m d r 1$ gene is located on chromosome 5 and pfcrt gene is located on chromosome 7 . The weight of molecular evidence suggests that while $p f m d r 1$ may have a modulatory effect in parasite susceptibility to CQ [6], mutation in $p f c r t$ is the principal determinant of CQR [7].

Several mutations have been identified in the pfcrt gene. CQR P. falciparum strains from South East Asia and Africa carry point mutations at codons 74, 75, 76, 220, 271, 326 and 371, whereas, CQR South American parasites carry point mutations at codons 76, 220 and either 72, 326 and 356 or 75,97 and 371 [8]. The (K76T) mutation is 
strongly associated with CQ susceptibility and clinical outcomes. Transfection studies have confirmed the importance of this amino acid change [9]. The PfCRT protein is localized to the digestive vacuole membrane and appears to be an integral membrane protein with an as yet unidentified transport function. Hypotheses have been proposed to explain CQR that implicate PfCRT function as either an ion channel or as a direct drug transporter. In addition to mutation in $p f c r t$ being involved in CQR, it has also been suggested that the level of $p f c r t$ expression has an impact on parasite susceptibility [10]. Waller et al demonstrated that lines transfected with $p f c r t$ alleles associated with CQR displayed a $30-40 \%$ reduction in protein expression together with an increase in CQ sensitivity [10]. In contrast, Durrand et al failed to identify any correlation between the CQ response of field isolates and pfcrt gene expression [11].

It is generally accepted that PfCRT is the principal determinant of CQR. However, it is not possible to predict the degree of CQR based on the pfcrt genotype alone or even in combination with $p f m d r 1$ genotype. It is clear form our own surveillance studies and those of others that parasites considered to be CQR in actual fact display a broad range of sensitivity to the drug. In this study, the phenotype-genotype relationship between 95 recently adapted isolates of $P$. falciparum from Thailand were characterized. Furthermore, 20 selected isolates were fully sequenced for $p f c r t$ gene in order to look for novel mutations that might be implicated in the degree of CQR.

\section{Methods}

Parasite isolates

Clinical P. falciparum isolates were collected from malaria endemic areas of Thailand including the ThaiMyanmar (Kanchanaburi, Tak, Ratchaburi and Ranong Provinces) and Thai-Combodian borders (Chantaburi Province) between 1998 and 2003 prior to the initiation of antimalarial treatment. Blood samples from individual patients were collected under a clinical protocol approved by the Ethics Committee of the Ministry of Public Health of Thailand. Briefly, three to five millilitres of blood were collected into EDTA tubes from patients with a confirmed diagnosis of uncomplicated $P$. falciparum malaria. The fresh blood samples were then centrifuged to remove the buffy coat and cryopreserved in liquid nitrogen following the method of Rowe et al [12] before being transported to Pharmacology and Toxicology Unit, Graduate Programme in Biomedical Sciences, Thammasat University.

\section{Parasite culture and drug susceptibility assay}

Parasites were maintained in in vitro culture using the method of Trager and Jensen [13]. In vitro susceptibility to chloroquine and a series of related compounds, in the presence or absence of verapamil was tested by monitoring $\left[{ }^{3} \mathrm{H}\right]$ Hypoxanthine uptake [14]. Briefly, each drug was prepared as $10 \mathrm{mM}$ in $50 \%$ ethanol for stock solution, and further diluted with RPMI-1640 complete media in desired concentrations. Each well in 96-well plate contained $100 \mathrm{ml}$ of drug solution and $10 \mathrm{ml}$ of $1 \%$ parasitaemia and $20 \%$ haematocrit. The plates were incubated at $37^{\circ} \mathrm{C}$ in gas chamber $\left(95 \% \mathrm{~N}_{2}, 5 \% \mathrm{O}_{2}, 5 \%\right.$ $\mathrm{CO}_{2}$ ) for 24 hours, then pulsed with $5 \mathrm{ml}$ of $\left[{ }^{3} \mathrm{H}\right]$ hypoxanthine solution $(0.1 \mathrm{mCi} / \mathrm{ml})$, and reincubated for an additional 24 hours. The plates were harvested and measured with a 1450 MicroBeta Trilux liquid scintillation and luminescence counter (Wallac Co. Ltd., Finland). The drug concentration that inhibited 50\% parasite growth $\left(\mathrm{IC}_{50}\right)$ were determined.

\section{PCR amplification of $P$. falciparum genes}

Genomic DNA was extracted using Chelex-resin (Biorad, USA) according to the method of Wooden et al [15]. Genetic variation between parasites was investigated by a multiplex PCR fingerprint technique [15]. Previously published nested and allele-restricted PCR methods were employed to detect pfmdr1 N86Y [16] and pfcrt mutations [7] respectively. For all assays, the laboratory adapted Thai $\mathrm{K} 1$ parasite isolate was used as a positive control for the mutant genotype and the Gambia isolate, G112 (a gift from the Malaria Research Unit, Chulalongkorn University, Thailand) as a positive control for the wild type genotype.

\section{DNA sequencing analysis}

The $p f c r t$ gene was amplified from genomic DNA using a nested PCR strategy. Exons 1-2, 3-8 and 9-13 were sequenced independently using the primers shown in Table 1. Each reaction contained $1.5 \mathrm{mM} \mathrm{MgCl}$, $200 \mathrm{mM}$ dNTPs, $1 \mathrm{mM}$ each primer, $1 \times$ PCR buffer and $2 \mathrm{U}$ of $\mathrm{Taq}$ polymerase (Promega, USA) in a total volume of $50 \mathrm{ml}$. The thermal cycle conditions were $94^{\circ}$ $\mathrm{C}$ for $3 \mathrm{~min}$, and $35 \mathrm{cycles}$ of $92^{\circ} \mathrm{C}$ for $30 \mathrm{sec}, 55^{\circ} \mathrm{C}$ for $30 \mathrm{sec}, 62^{\circ} \mathrm{C}$ for $1 \mathrm{~min} 30 \mathrm{sec}$ and a final extension at $62^{\circ} \mathrm{C}$ for $5 \mathrm{~min}$. The second round of amplification for exon $1-2$ was $94^{\circ} \mathrm{C}$ for $4 \mathrm{~min}, 35$ cycles of $92^{\circ} \mathrm{C}$ for 1 min, $60^{\circ} \mathrm{C}$ for $1 \mathrm{~min}, 72^{\circ} \mathrm{C}$ for $1 \mathrm{~min}$ and a final extension step of $72^{\circ} \mathrm{C}$ for $5 \mathrm{~min}$. PCR products were purified using Wizard SV gel and PCR clean up system (Promaga, USA) according to the manufacturers instructions. Each amplicon was then cloned with the TOPO TA Cloning kit (Invitrogen Life Technologies) and the positive clones were picked from white or blue colonies following overnight incubation in selection media, S-Gal (Sigma, USA). The plasmid DNA was purified using a MiniPrep Kit (Promega, USA) and digested with the restriction enzyme EcoRI to confirm the correct 
Table 1 Primers used for pfort sequencing and real-time PCR quantification

\begin{tabular}{|c|c|}
\hline \multicolumn{2}{|l|}{ Exon $1-2$} \\
\hline \multicolumn{2}{|l|}{ Primary } \\
\hline$E 1 / 2-F$ & CGACATTCCGATATATTATATITITAGAC \\
\hline$E 1 / 2-R$ & TATATGTGTAATGTITTATATTGG \\
\hline \multicolumn{2}{|l|}{ Nested } \\
\hline E1/2-NF & CCGTTAATAATAAATACACGCAG \\
\hline E1/2-NR & AATGTITTATATTGGTAGGTGG \\
\hline \multicolumn{2}{|l|}{ Exon 3-8 } \\
\hline \multicolumn{2}{|l|}{ Primary } \\
\hline$E 3 / 8-F$ & CCACCTACCAATATAAAACATTAC \\
\hline$E 3 / 8-R$ & GTTAAAATATATATAAATGTCTC \\
\hline \multicolumn{2}{|l|}{ Nested } \\
\hline E3/8-NF & TATATATATATGTATGTATGTTG \\
\hline E3/8-NR & AATGTCTCTTATAATTTTGAAATT \\
\hline \multicolumn{2}{|c|}{ Exon $9-13$} \\
\hline \multicolumn{2}{|l|}{ Primary } \\
\hline E9/13-F & СTTATAATAAAATTTCAAAATTATAAGAGAC \\
\hline E9/13-R & GAGATCTCTATACCTTCAACATTATTCC \\
\hline \multicolumn{2}{|l|}{ Nested } \\
\hline $\begin{array}{l}\text { E9/13- } \\
\text { NF }\end{array}$ & GAGACATTTATATATATITTAAC \\
\hline $\begin{array}{l}E 9 / 13- \\
N R\end{array}$ & CCTTATAAAGTGTAATGCG \\
\hline \multicolumn{2}{|l|}{ pfcrt RT-PCR } \\
\hline pfcrt-F & CTTATTTGTATGATTATGTTCTTTATTGTTTATTCCTTATTTGGA \\
\hline pfcrt-R & AACAGGCATCTAACATGGATATAGCAAA \\
\hline \multicolumn{2}{|l|}{$\begin{array}{l}\text { pfmdr RT- } \\
\text { PCR }\end{array}$} \\
\hline pfmdr-F & GCATTCGGTITITGGTATGGTACAA \\
\hline pfmdr-R & CCTAATAAAATGGATATAACTGAGGCACCA \\
\hline pfmdr-probe & ACGAATCAATACCCCAATAAT \\
\hline \multicolumn{2}{|c|}{$\begin{array}{l}\text { EF-1a RT- } \\
\text { PCR }\end{array}$} \\
\hline EF-1a-F & GGCAGAAAGAGAAAGAGGTATTACCA \\
\hline EF-1a-R & CCTGGTGCATCAATGACAGTAAAGA \\
\hline EF-1a-probe & TTATGGAAATTTGAAACCCC \\
\hline
\end{tabular}

insertion. Finally, sequencing was carried out using the M13 forward and reverse primers and DNAstar (Lasergene) was utilized for sequence analysis.

\section{Pfcrt and pfmdr1 real-time reverse transcription PCR quantification}

Pfcrt and $p f m d r 1$ gene expression were determined by real-time reverse transcription PCR. Since $p f c r t$ and $p f m d r 1$ have previously been reported to be preferentially expressed during the trophozoite state, analysis was restricted to isolates at the trophozoite stage. Total RNA was extracted by standard methodology using Trizol $^{\text {TM }}$ (Invitrogen, USA) [17]. For $p f c r t$, EF-1a primers were designed to cross introns. However, this was not possible for $p f m d r 1$ since it is a one-exon gene. Therefore, each sample was treated with DNase prior to reverse transcription (Invitrogen, USA) in order to negate the possibility of amplifying genomic DNA. The sequences of forward and reverse primers as well as the sequences of the specific reporter probes (FAM-labelled in all cases) are shown in Table 1. Quantification was achieved by standard taqMan methodology as previously reported [18].

Detection of gene copy number of pfmdr1 by SYBR Green I real-time $P C R$

Pfmdr1 copy number was determined by SYBR Green I real-time PCR (iCycler, Bio-Rad, USA) using the default thermocycler program for all genes: 10 minutes of preincubation at $95^{\circ} \mathrm{C}$ followed by 40 cycles for 15 seconds at $95^{\circ} \mathrm{C}$ and one minute at $60^{\circ} \mathrm{C}$. The oligonucleotide primers were designed by Ferreira [19] with modification. Individual real-time PCR reaction was carried out in $25 \mu \mathrm{l}$ volume in a 96-well plate containing $1 \times$ buffer (10×), $3.5 \mathrm{mM} \mathrm{MgCl} 2,200 \mu \mathrm{M}$ dNTPs, $1 \mathrm{mM}$ each of sense and antisense primers, $12.5 \mathrm{ml}$ of Platinum ${ }^{\mathrm{TM}}$ PCR SuperMix (Invitrogen, USA). The $2^{-\Delta \Delta \mathrm{Ct}}$ method of relative quantification was adapted to estimate copy numbers in P. falciparum genes. In this work, genomic DNA extracted from P. falciparum 3D7, known to harbour a single copy of each gene studied, was used as a calibrator, while Pf- $\beta$-actin 1 was served as the house-keeping gene in all experiments. Dd2 genomic DNA was used as a second calibrator containing four copies of pfmdr1. A minimum of two experiments was carried out for each gene and each sample. In each experiment, each individual sample was run in duplicate wells and the $C_{t}$ of each well was recorded at the end of the reaction.

\section{Statistical analysis}

All data are expressed as mean \pm standard deviation. Data were assessed for normality using a Shapiro-Wilk statistical test. A Kruskal-Wallace statistical test was utilized to assess the relationship between mutations in $p f c r t$ and $p f m d r 1$ and drug $\mathrm{IC}_{50}$. Correlations were assessed by Spearman Rank test. Statistical significance for all tests was set at a $\alpha=0.05$.

\section{Results}

Genetic polymorphisms of $P$. falciparum isolates

A total of 95 isolates (excluding the laboratory lines: K1, G112, M12 and T9/94b3) were successfully cultured and analysed. Of these, 13 were obtained from the Tak Province of Thailand, 37 from Kanchanaburi, 16 from Ranong, 1 from Ratchaburi, and 14 were from Chantaburim Provinces. Fourteen isolates were of unknown origin. Tak, Kanchanaburi and Ranong are provinces that lie along the Thai-Myanmar border; the first two areas have been described as 'high mefloquine-resistance 
areas', whereas the third is described as a 'low mefloquine-resistance area'. Chantaburi Province is located along the Thai-Cambodian border and is defined as a 'high mefloquine-resistance area' (Ministry of Public Health, Thailand [20].

Based on the results of the PCR fingerprints, all but two infections were clonal containing only one parasite population with a single genotype of either $m s p 1, m s p 2$ or csp. Two isolates showed PCR fingerprint suggesting a mixed-infection. Genotyping for pfcrt revealed a $100 \%$ prevalence of the $76 \mathrm{~T}, 220 \mathrm{~S}, 271 \mathrm{E}, 326 \mathrm{~S}$ and $371 \mathrm{I}$ mutations (95 of 95 samples) with a $94 \%$ prevalence of the $356 \mathrm{~T}$ Mutation (89 of 95 samples). The K1-type mutation of the pfmdr1 was seen in only $5 \%$ (5 of 95) of the samples with almost all isolates containing the wild type Asn at position 86.

\section{In vitro drug sensitivity test}

A total of 90 isolates were tested for sensitivity to chloroquine $(C Q)$, quinine $(\mathrm{QN})$, mefloquine $(\mathrm{MQ})$, and dihydroartemisinin (DHA). The sensitivity of the isolates to $\mathrm{CQ}$ and $\mathrm{QN}$ was also assessed in the presence or absence of the resistance reverser verapamil (VP: $5 \mathrm{mM}$ ). Sensitivity of the isolates to $\mathrm{CQ}, \mathrm{QN}$ and $\mathrm{MQ}$ was categorized based on $\mathrm{IC}_{50}$ values described by Cerutti et al, [21].

CQ sensitivity was categorized into either highly resistant (HR: $\mathrm{IC}_{50}>101 \mathrm{nM}$ ), moderately resistant (MR: $\left.30.9<\mathrm{IC}_{50} \leq 100.9 \mathrm{nM}\right)$ or sensitive $\left(\mathrm{S}: \mathrm{IC}_{50} \leq 30.9 \mathrm{nM}\right)$ (Figure 1A). Based on these criteria, 30 (32\%), 61 (64\%), and $4(4 \%)$ isolates were categorized as $\mathrm{HR}$, MR, and S, respectively. The corresponding values for geometric mean (95\% CI) $\mathrm{IC}_{50}$ were 130.9 (122.1-140.2), 60.8
(56.7-65.3), and 23.0 (20.5-25.5) nM, respectively. All resistant isolates demonstrated a verapamil reversible component of resistance.

QN sensitivity was categorized as either resistant (R: $\mathrm{IC}_{50}>500 \mathrm{nM}$ ) or sensitive (S: $\left.\mathrm{IC}_{50} \leq 500 \mathrm{nM}\right)$. Based on these criteria, $1(1 \%)$, and $92(99 \%)$ isolates were categorized as $\mathrm{R}$, and $\mathrm{S}$, respectively. The corresponding values for geometric mean $(95 \% \mathrm{CI}) \mathrm{IC}_{50}$ were 654.4 and 144.4 (129.4-161) nM, respectively. All isolates were chemosensitized verapamil.

MQ sensitivity was categorized as either resistant (R: $\mathrm{IC}_{50}>24 \mathrm{nM}$ ) or sensitive (S: $\mathrm{IC}_{50} \leq 24 \mathrm{nM}$ ) (Figure 1B). Based on these criteria, $44(32 \%)$, and $47(68 \%)$ isolates were categorized as $\mathrm{R}$, and $\mathrm{S}$, respectively. The corresponding values for geometric mean $(95 \% \mathrm{CI}) \mathrm{IC}_{50}$ were 38.2 (34.4-42.4), and 13.3 (11-16) nM, respectively.

The $\mathrm{IC}_{50}$ of DHA for different isolates ranged from 0.37 to $4.87 \mathrm{nM}$, with the geometric mean $(95 \% \mathrm{CI})$ of $1.42(1.24-1.64) \mathrm{nM}$.

\section{The relationship between genotype and phenotype}

Based on the known mutations in pfcrt and pfmdr1, there was no statistically significant association between susceptibility of $P$. falciparum isolates to $\mathrm{CQ}, \mathrm{QN}$ and $\mathrm{MQ}$ and $p f c r t$ polymorphisms, as well as between susceptibility to CQ and QN and pfmdr1 polymorphisms. However, there was a tendency (no statistical significance) of reduced MQ susceptibility in $p f m d r 1$ mutant isolates.

\section{Novel sequence polymorphisms in pfort}

A total of 20 isolates selected from either the moderately or highly CQ resistant subgroups were fully
A

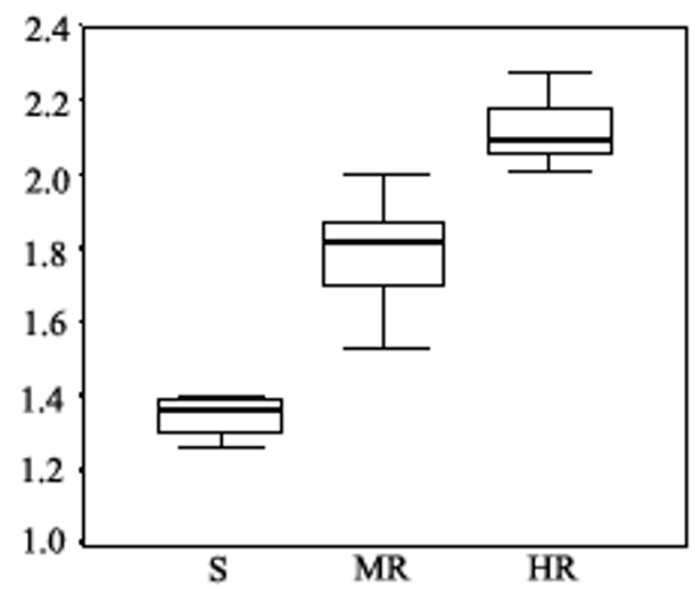

B

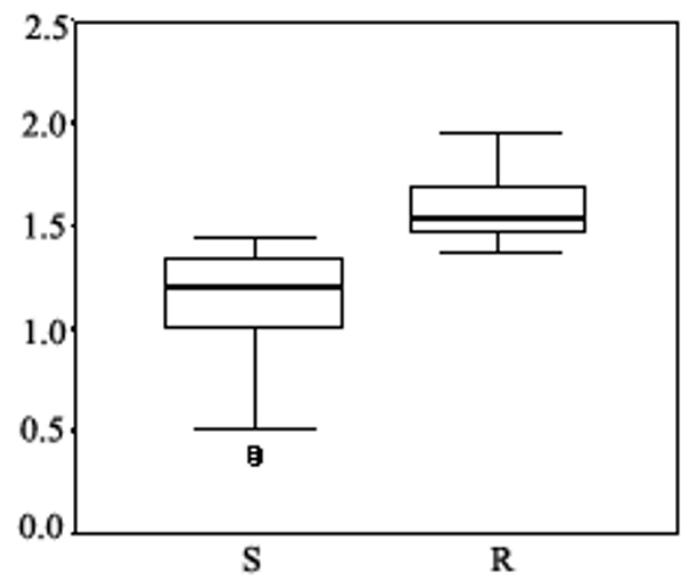

Figure 1 Box plot between $\log \mathrm{IC}_{50}$ and the order of drug susceptibility. A: CQ was categorised into high resistance $\left(H R: I C_{50}>101 \mathrm{nM}\right)$, moderate resistance (MR: $\left.30.9<I C_{50} \leq 100.9 \mathrm{nM}\right)$ and sensitive $\left(S_{;} I C_{50} \leq 30.9 \mathrm{nM}\right)$. B: MQ was divided into 2 groups; resistant $\left(R ; I C_{50}>24 \mathrm{nM}\right.$ and sensitive $\left(S_{;} I_{C_{50}} \leq 24 \mathrm{nM}\right)$. 
sequenced for the pfcrt gene in order to establish if other, as yet unknown mutations could discriminate between these two levels of in vitro susceptibility. The derived sequences were compared with the sequences of the 3D7 and Dd2 parasites from the PlasmoDB database. The sequencing results are summarized in Table 2 . There were several new mutations identified at a number of novel positions, which conferred an amino acid alteration compared to 3D7. However, it was not possible in this study to directly link these sequence differences with CQ susceptibility. Although most of the parasites had the familiar "CVIET" sequence at positions 72-76, the J9 isolate from Chantaburi contained the novel mutation at codon 76 with a different amino acid substitution K76A. This is a unique position 76 mutation, which has never been reported before in field isolates. In addition, this field isolate carried other mutations at positions S39P and N277D.

Four of the field isolates categorized as displaying moderate CQ resistance carried a E198K mutation which may be functionally relevant. Furthermore, deletions in the $p f c r t$ sequence were observed at position 327 in isolate BC7 and 251 in isolate KS28. These two deletions occurred at exon 2. Interestingly, the A144T or A144F mutation newly described in isolates from the Philippines and Cambodia was not detected in these Thai isolates $[8,22]$.

\section{Pfcrt and pfmdr1 gene expression}

The correlation between $p f c r t$ and $p f m d r 1$ gene expression (determined by RT-PCR) and in vitro response is shown in Figures 2 and 3. In this study, there was no statistically significant correlation between expression levels of either gene and sensitivity to $C Q, Q N$ or $M Q$. Although statistical significance was not achieved, a trend toward higher $p f m d r 1$ expression levels in MQ sensitive isolates was observed $(p=0.094)$.

Interestingly, expression of pfcrt mRNA could not be detected in two isolates ( $\mathrm{BC} 1$ and $\mathrm{J} 1)$ despite confirmation of EF-1a gene expression performed on several occasions. This was not due to any primer mismatch and did not appear to relate to experimental difficulties, although all possibilities cannot be ruled out. This observation needs to be carefully followed up as it has been shown that a pfcrt knockout is fatal for the parasite [10].

Table 2 Sequence polymorphism in pfort

\begin{tabular}{|c|c|c|c|c|c|c|c|c|c|c|c|c|}
\hline \multirow[t]{2}{*}{ Isolate/clone } & \multirow[t]{2}{*}{$\mathrm{CQ} I \mathrm{C}_{50}(\mathrm{nM})$} & \multicolumn{11}{|c|}{ Amino acid in pfcrt gene } \\
\hline & & 72 & 73 & 74 & 75 & 76 & 198 & 220 & 271 & 326 & 356 & 371 \\
\hline 3D7 & 8 & C & V & M & N & K & E & A & Q & $\mathrm{N}$ & । & R \\
\hline $\mathrm{Dd} 2$ & 48 & $C$ & V & I & E & $T$ & $E$ & $S$ & E & $S$ & $T$ & I \\
\hline $\mathrm{BC1}$ & 76 & $C$ & V & I & $E$ & $T$ & $E$ & $\mathrm{~S}$ & $E$ & $S$ & $T$ & I \\
\hline BC7 & 54 & $C$ & V & 1 & E & $T$ & $E$ & $S$ & E & $S$ & $T$ & I \\
\hline $\mathrm{BC} 12$ & 49 & $C$ & V & 1 & E & T & E & S & E & S & T & । \\
\hline BC22 & 42 & C & V & 1 & $E$ & $T$ & $K^{*}$ & $S$ & $E$ & $S$ & $\mathrm{~T}$ & 1 \\
\hline BC31 & 31 & C & V & 1 & E & $\mathrm{T}$ & $K^{*}$ & $S$ & E & $S$ & T & 1 \\
\hline $\mathrm{BC} 35$ & 57 & C & V & 1 & $E$ & $T$ & $K^{*}$ & $\mathrm{~S}$ & $E$ & $S$ & $T$ & 1 \\
\hline$J 1$ & 107 & C & V & 1 & $E$ & $T$ & $E$ & $S$ & $E$ & $S$ & $T$ & 1 \\
\hline $\mathrm{J3}$ & 119 & $C$ & $V$ & 1 & $E$ & $T$ & $E$ & $\mathrm{~S}$ & $E$ & $S$ & $T$ & 1 \\
\hline 14 & 114 & C & V & 1 & $E$ & $T$ & $E$ & $S$ & $\mathrm{E}$ & $S$ & $T$ & 1 \\
\hline$J 5$ & 121 & C & V & 1 & $E$ & $T$ & $E$ & $S$ & E & $S$ & $T$ & I \\
\hline$J 6$ & 167 & $C$ & V & 1 & $E$ & $T$ & $E$ & $S$ & $E$ & $S$ & $T$ & 1 \\
\hline J9 & 123 & $C$ & V & 1 & $E$ & $A^{* *}$ & $E$ & $S$ & $E$ & $S$ & $T$ & 1 \\
\hline KS14 & 67 & $C$ & V & 1 & $E$ & $\mathrm{~T}$ & $E$ & $S$ & E & $S$ & T & I \\
\hline KS21 & 68 & C & V & 1 & $E$ & $T$ & $E$ & $S$ & $E$ & $S$ & $T$ & 1 \\
\hline KS28 & 74 & C & V & 1 & $E$ & $T$ & $E$ & $S$ & $E$ & $S$ & $\mathrm{~T}$ & 1 \\
\hline KS33 & 55 & $C$ & $\mathrm{~V}$ & 1 & $E$ & $\bar{T}$ & $E$ & $S$ & $E$ & $S$ & $T$ & 1 \\
\hline KS50 & 78 & $C$ & V & 1 & $E$ & $T$ & $K^{*}$ & $\mathrm{~S}$ & $E$ & $S$ & $T$ & 1 \\
\hline PCM2 & 75 & $C$ & V & 1 & $E$ & $T$ & $E$ & $S$ & $E$ & $S$ & $T$ & 1 \\
\hline PCM7 & 51 & $C$ & V & 1 & $E$ & $T$ & $E$ & $S$ & $E$ & $S$ & $T$ & 1 \\
\hline RN54 & 47 & $C$ & $\mathrm{~V}$ & 1 & $E$ & $T$ & $E$ & $S$ & $E$ & $S$ & $T$ & I \\
\hline
\end{tabular}

* Glutamic acid $=>$ Lysine.

* Lysine $==>$ Alanine. 

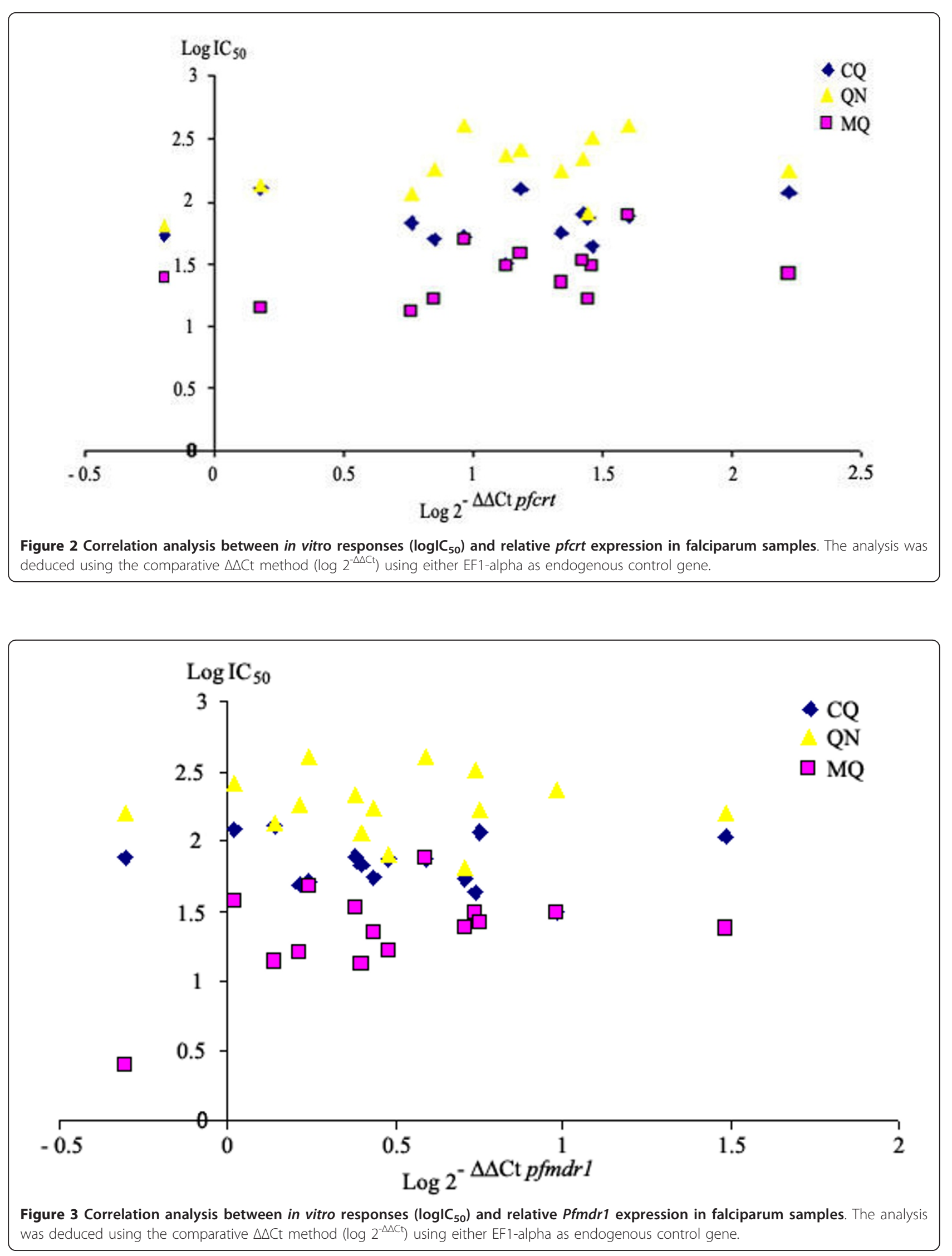


\section{Pfmdr1 copy number}

The $p f m d r 1$ copy number was determined by SYBR Green I real-time PCR. The average copy number of Dd2 was 4.4 , which was similar to that previously reported [19]. The $p f m d r 1$ gene copy number was neither correlated to mRNA expression nor in vitro drug susceptibility.

\section{Discussion}

Thailand and its borders have historically been linked with the early emergence of drug resistant parasites. The first report of CQ resistance came from this region in the late 1950's. MQ resistance was reported shortly after its deployment, a situation which was worsened despite doubling the drug dosage for treatment. More recently, the Malaria Control Programme of Thailand has introduced artesunate, an artemisinin derivative, deployed in combination with mefloquine to control these multidrug resistant parasites. With respect to CQ susceptibility, molecular studies have confirmed the role for mutation in the pfcrt gene and CQR with a possible modulatory influence coming from the $p f m d r 1$ gene. In contrast, MQ susceptibility has been linked to mutation $[6,23,24]$ and gene copy number of $p f m d r 1$ [25]. Despite these linkage data, a wide range of observations cannot be fully explained by the currently available genetic evidence. In this study, this issue was investigated in more detail using isolates recently collected from distinct regions of Thailand.

It is unquestionable that genetic polymorphisms of parasite transporter genes have affected the susceptibility to various drugs. In early studies of multidrug resistance in South East Asia, single nucleotide polymorphisms (SNPs) in pfmdrl gene such as N86Y have been identified [26]. In Africa, where the 4-aminoquinoline is the main drug for malaria treatment, the frequency of N86Y polymorphism is high $(>50 \%)[12,16,27-29]$. However the frequency of N86Y mutation observed in the present study was relatively low, which is in agreement with its frequency in other South East Asian isolates [3,27,30-33]. This might be due to the influence of MQ pressure since mid 1980s after CQ was dismissed in this region [25,34].

Whilst the association of $p f m d r 1$ polymorphisms and drug sensitivity is still a matter of debate, the level of expression of $p f m d r 1$ seems to offer a better explanation of anti-malarial drug sensitivity profiles, especially for $\mathrm{MQ}, \mathrm{QN}$ and artemisinin derivatives. Previous studies have shown the relationship between the increase of $p f m d r 1$ gene copy number and multidrug resistance phenotypes including artesunate [35-39]. In one study, over-expression of $p f m d r 1$ was found to be correlated with MQ resistance [40]. On the basis that an increase of gene copy number or gene over-expression may be expected to result in a rise in the mRNA, the levels of pfmdr1 mRNA and copy number were compared. It is very surprising; the level of mRNA was not correlated to gene copy number. Results failed to reveal an association between $p f m d r 1$ expression or gene copy number and drug sensitivity. This is analogous to the reported absence of association between Pgh1 protein expression and CQ sensitivity [41]. The authors note that two isolates ( $\mathrm{BC} 1$ and J1), which lack $p f c r t$ expression have different $p f m d r 1$ expression. For the J1 isolate, of which pfmdr1 expression was approximately 70-fold over BC1, showed reduced sensitivity to both $C Q$ and $M Q$. Although the trend of correlation between $p f m d r 1$ expression and sensitivity to MQ was observed, due to small number of sample size, a statistically significant correlation could not be achieved. These data suggest that increase of copy number and over-expression of $p f m d r 1$ gene may not necessarily confer drug resistance on its own. Nevertheless, the expression and polymorphism of $p f m d r 1$ may make a major contribution to drug resistance when present in conjunction with the mutation of other genes [6].

Several studies have described gene mutations in association with CQ-resistance but the exact mechanism of resistance remains unclear. The K76T mutation of $p f c r t$ is reported to be highly associated with CQ-resistance. The frequency of this mutation is almost $100 \%$ in Thailand. Consequently there seems to be no link between the frequency of this gene mutation and CQ sensitivity. Parasites carrying the K76T mutation with comparable patterns of other pfcrt gene mutations still showed a variable degree of CQ-resistance. In fact, the pfcrt polymorphisms were similar in all Thai isolates but drug sensitivity profiles were completely different. Data reported from other South East Asian countries, i.e., Philippines, showed different mutations carrying K76T and N326D without 220S residue, together with the novel mutations A144T and L160Y [42]. Furthermore, four novel mutations A144F, L148I, I194T and T333S were observed from Cambodian isolates [11]. These mutation patterns were not observed in Thailand. This suggests that CQ-resistance emerged simultaneously but independently in these neighboring endemic regions.

Pfcrt polymorphism pattern CVIET was found in all isolates. This pattern is unique to P. falciparum isolates from South East Asia. The CVIET pattern, which is different from SVMNT pattern of South America, is more responsive to the calcium channel-blocker verapamil. The chemosensitization phenomenon of verapamil was observed for all isolates even the isolates with lower sensitivity to CQ. Therefore, the CVIET polymorphism pattern seems to confer chemosensitization by verapamil and related compounds.

Full pfcrt sequencing revealed the novel 76 haplotype K76A in one isolate. Previously, the substitution of 
other amino acids at this codon, i.e., K76I and/or K76N has been reported only in laboratory strains $[7,43]$. This allelic type replaces lysine (positively charged amino acid) with alanine (non-charged amino acid), similar to the charge loss found with K76T, K76I and K76N mutations. These data augment the growing body of evidence that substitution of non-charged amino acid appears to result in resistance of the parasite to CQ. In addition, the new mutation at position E198K was detected in 4 out of 20 isolates with high CQ sensitivity (low $\mathrm{IC}_{50}$ ). Based on amino acid sequence, it is speculated that E198K might be located in the fifth of ten PFCRT transmembrane regions, with substitution of glutamic acid (negative charge) to lysine (positive charge). The additional mutation in this position may be critical to the loss of resistance of these parasites to CQ. These findings may support the proposed hypothesis that CQR results from a "charged drug leak", in which the loss of positive charge in the channel of PfCRT might allow the protonated species of $C Q$ to leak out of the digestive vacuole, thus reducing vacuolar $C Q$ concentration and ultimately conferring resistance [44].

Results obtained from transfection studies showed significant correlation between the extent of protein expression and drug sensitivity profile (increased resistance with increased expression) [10]. In contrast, recent observation of pfcrt expression and parasites from field isolates showed no correlation between level of mRNA expression and CQ sensitivity [11]. In our study, such absence of correlation between level of mRNA expression and CQ sensitivity was also observed. Furthermore, it was found that no mRNA expression was observed in two isolates. This finding was in contrast with the previous report showing that the knockout of $p f c r t$ gene would lead the parasite to death. The undetectable level of mRNA expression could be explained by the low or totally absence of $p f c r t$ expression, or the fact that gene expression may not entirely represent protein expression due to post-transcription process.

\footnotetext{
Acknowledgements

This work was supported by The Commission on Higher Education, Ministry of Education of Thailand, the National Research University Project of Thailand (NRU), Office of Higher Education Commission and Thailand Research Fund for the scholarship of The Royal Golden Jubilee (RGJ) Ph.D. Program to W.C. K.N. and M.M. were supported by Thailand-Tropical Disease Research Programme (T2), ID 02-2-MAL-24-047. PGB is supported by the $M R C$ and the BBSRC

\section{Author details}

${ }^{1}$ Faculty of Allied Health Sciences, Thammasat University, Rangsit, Patumthani 12120, Thailand. ${ }^{2}$ Division of Molecular and Biochemical Parasitology of Liverpool, University of Liverpool, Pembroke Place, Liverpool L35QA, UK. ${ }^{3}$ Department of Parasitology, Phramongkutklao College of Medicine, Ratchathewi, Bangkok 10400, Thailand. ${ }^{4}$ Department of Pharmacology and Therapeutics, University of Liverpool, Pembroke Place, Liverpool L35QA, UK.
}

\section{Authors' contributions}

WC performed the molecular genetic studies, participated in the sequence alignment, interpretation of data, performed the statistical analysis and drafted the manuscript. SA participated in the design of the study and data analysis. MM participated in sample collection and in vitro sensitivity test. DJ, $\mathrm{AO}$ and PB participated in the molecular genetic studies and sequence alignment. KN participated in the design of the study and finalized the manuscript. All authors read and approved the final manuscript.

\section{Competing interests}

The authors declare that they have no competing interests.

Received: 26 October 2010 Accepted: 15 February 2011

Published: 15 February 2011

\section{References}

1. Wongsrichanalai $C$, Pickard AL, Wernsdorfer WH, Meshnick SR: Epidemiology of drug-resistant malaria. Lancet Infect Dis 2002, 2:209-218.

2. Bray PG, Howells RE, Ward SA: Vacuolar acidification and chloroquine sensitivity in Plasmodium falciparum. Biochem Pharmacol 1992, 43:1219-1227.

3. Chaiyaroj SC, Buranakiti A, Angkasekwinai P, Looressuwan S, Cowman AF: Analysis of mefloquine resistance and amplification of pfmdr 1 in multidrug-resistant Plasmodium falciparum isolates from Thailand. Am J Trop Med Hyg 1999, 61:780-783.

4. Krogstad DJ, Schlesinger PH: The basis of antimalarial action: non-weak base effects of chloroquine on acid vesicle pH. Am J Trop Med Hyg 1987, 36:213-220.

5. Verdier F, Le Bras J, Clavier F, Hatin I, Blayo M: Chlorquine uptake by Plasmodium falciparum-infected human erythrocytes during in vitro culture and its relationship to chloroquine resistance. Antimicrob Agents Chemother 1985, 27:561-564.

6. Reed MB, Saliba KJ, Caruana SR, Kirk K, Cowman AF: Pgh1 modulates sensitivity and resistance to multiple antimalarials in Plasmodium falciparum. Nature 2000, 403:906-909.

7. Fidock DA, Nomura T, Talley AK, Cooper RA, Dzekunov SM, Ferdig MT, Ursos LM, Sidhu AB, Naude B, Deitsch KW, Su XZ, Wootton JC, Roepe PD, Wellems TE: Mutations in the $P$. falciparum digestive vacuole transmembrane protein PfCRT and evidence for their role in chloroquine resistance. Mol Cell 2000, 6:861-871.

8. Howard EM, Zhang H, Roepe PD: A novel transporter, Pfcrt, confers antimalarial drug resistance. J Membr Biol 2002, 190:1-8.

9. Sidhu $A B$, Verdier-Pinard D, Fidock DA: Chloroquine resistance in Plasmodium falciparum malaria parasites conferred by pfcrt mutations. Science 2002, 298:210-213.

10. Waller KL, Muhle RA, Ursos LM, Horrocks P, Verdier-Pinard D, Sidhu AB, Fujioka $\mathrm{H}$, Roepe PD, Fidock DA: Chloroquine resistance modulated in vitro by expression levels of the Plasmodium falciparum chloroquine resistance transporter (PfCRT). J Biol Chem 2003, 278:33593-33601.

11. Durrand V, Berry A, Sem R, Glaziou P, Beaudou J, Fandeur T: Variations in the sequence and expression of the Plasmodium falciparum chloroquine resistance transporter (Pfcrt) and their relationship to chloroquine resistance in vitro. Mol Biochem Parasitol 2004, 136:273-285.

12. Rowe AW, Eyster E, Kellner A: Liquid nitrogen preservation of red blood cells for transfusion; a low glycerol-rapid freeze procedure. Cryobiology 1968, 5:119-128.

13. Trager $W$, Jensen JB: Human malaria parasites in continuous culture. Science 1976, 193:673-675.

14. Desjardins RE, Canfield CJ, Haynes JD, Chulay JD: Quantitative assessment of antimalarial activity in vitro by a semiautomated microdilution technique. Antimicrob Agents Chemother 1979, 16:710-718.

15. Wooden J, Gould EE, Paull AT, Sibley CH: Plasmodium falciparum: a simple polymerase chain reaction method for differentiating strains. Exp Parasitol 1992, 75:207-212.

16. Djimde A, Doumbo OK, Cortese JF, Kayentao K, Doumbo S, Diourte Y, Dicko A, Su XZ, Nomura T, Fidock DA, Wellems TE, Plowe CV, Coulibaly D: A molecular marker for chloroquine-resistant falciparum malaria. $N$ Engl J Med 2001, 344:257-263.

17. Chomczynski P: A reagent for the single-step simultaneous isolation of RNA, DNA and proteins from cell and tissue samples. Biotechniques 1993, 15:532-534. 
18. Owen A, Chandler B, Bray PG, Ward SA, Hart CA, Back DJ, Khoo SH: Functional correlation of P-glycoprotein expression and genotype with expression of the human immunodeficiency virus type 1 coreceptor CXCR4. J Virol 2004, 78:12022-12029.

19. Ferreira ID, Rosario VE, Cravo PV: Real-time quantitative PCR with SYBR Green I detection for estimating copy numbers of nine drug resistance candidate genes in Plasmodium falciparum. Malar J 2006, 5:1.

20. Vijaykadga S, Rojanawatsirivej C, Cholpol S, Phoungmanee D, Nakavej A, Wongsrichanalai C: In vivo sensitivity monitoring of mefloquine monotherapy and artesunate-mefloquine combinations for the treatment of uncomplicated falciparum malaria in Thailand in 2003. Trop Med Int Health 2006, 11:211-219.

21. Cerutti C Jr, Marques AC, de Alencar FEC, Durlacher RR, Alween A, Segurado AAC, Pang L, Zalis MG: Antimalarial drug susceptibility testing of Plasmodium falciparum in Brazil using a radioisotope method. Mem Inst Oswaldo Cruz 1999, 94:803-809.

22. Price RN, Uhlemann AC, Brockman A, McGready R, Ashley E, Phaipun L, Patel R, Laing K, Looareesuwan S, White NJ, Nosten F, Krishna S: Mefloquine resistance in Plasmodium falciparum and increased pfmdr1 gene copy number. Lancet 2004, 364:438-447.

23. Basco LK, Ringwald P: Molecular epidemiology of malaria in Cameroon. X. Evaluation of PFMDR1 mutations as genetic markers for resistance to amino alcohols and artemisinin derivatives. Am J Trop Med Hyg 2002, 66:667-671.

24. Duraisingh MT, Jones $P$, Sambou I, von Seidlein L, Pinder M, Warhurst DC: The tyrosine-86 allele of the pfmdr1 gene of Plasmodium falciparum is associated with increased sensitivity to the anti-malarials mefloquine and artemisisnin. Mol Biochem Parasitol 2000, 108:13-23.

25. Price RN, Cassar C, Brockman A, Duraisingh M, Van Vugt M, White NJ, Nosten F, Krishna S: The pfmdr 1 gene is associated with a multidrugresistant phenotype in Plasmodium falciparum from the western border of Thailand. Antimicrob Agents Chemother 1999, 43:2943-2949.

26. Foote SJ, Kyle DE, Martin RK, Oduola AM, Forsyth K, Kemp DJ, Cowman AF: Several alleles of the multidrug-resistance gene are closely linked to chloroquine resistance in Plasmodium falciparum. Nature 1990, 345:255-258.

27. Adagu IS, Warhurst DC: Plasmodium falciparum: linkage disequilibrium between loci in chromosomes 7 and 5 and chloroquine selective pressure in Northern Nigeria. Parasitology 2001, 123:219-224.

28. Randrianarivelojosia M, Raherinjafy $\mathrm{RH}$, Mercereau-Puijalon O, Ariey F, Bedja SA: Plasmodium falciparum resistant to chloroquine and to pyrimethamine in Comoros. Parasite 2004, 11:419-423.

29. Thomas SM, Ndir O, Dieng T, Mboup S, Wypij D, Maguire JH, Wirth DF: In vitro chloroquine susceptibility and PCR analysis of pfort and pfmdr1 polymorphisms in Plasmodium falciparum isolates from Senegal. Am J Trop Med Hyg 2002, 66:474-480.

30. Huaman MC, Yoshinaga K, Suryanatha A, Suarsana N, Kanbara H: Short report: polymorphisms in the chloroquine resistance trasporter gene in Plasmodium falciparum isolates from Lombok, Indonesia. Am J Trop Med Hyg 2004, 71:40-42.

31. Labbe AC, Bualombai P, Pillai DR, Zhong KJ, Vanisaveth V, Hongvanthong B, Looareesuwan S, Kain KC: Molecular markers for chloroquine-resistant Plasmodium falciparum malaria in Thailand and Laos. Ann Trop Med Parasitol 2001, 95:781-788.

32. Lim P, Chy S, Ariey F, Incardona S, Chim P, Sem R, Denis MB, Hewitt S, Hoyer S, Socheat D, Merecreau-Puijalon O, Fandeur T: Pfcrt polymorphism and chloroquine resistance in Plasmodium falciparum strains isolated in Cambodia. Antimicrob Agents Chemother 2003, 47:87-94.

33. Vathsala PG, Pramanik A, Dhanasekaran S, Devi CU, Pillai CR, Subbarao SK, Ghosh SK, Tiwari SN, Sathyanarayan TS, Deshpande PR, Mishra GC, Dash AP, Ranqarajan PN, Padmanaban G: Widespread occurrence of the Plasmodium falciparum chloroquine resistance transporter (Pfcrt) gene haplotype SVMNT in P. falciparum malaria in India. Am J Trop Med Hyg 2004, 70:256-259.

34. Sisowath C, Ferreira PE, Bustamante LY, Dahlstrom S, Martensson A, Bjorkman A, Krishna S, Gil JP: The role of pfmdr1 in Plasmodium falciparum tolerance to artemether-lumefantrine in Africa. Trop Med Int Health 2007, 12:736-742.

35. Basco LK, de Pecoulas PE, Le Bras J, Wilson CM: Plasmodium falciparum: molecular characterization of multidrug-resistant Cambodian isolates. Exp Parasitol 1996, 82:97-103.
36. Basco LK, Le Bras J, Rhoades Z, Wilson CM: Analysis of pfmdr1 and drug susceptibility in fresh isolates of Plasmodium falciparum from subsaharan Africa. Mol Biochem Parasitol 1995, 74:157-166.

37. Zalis MG, Pang L, Silveira MS, Milhous WK, Wirth DF: Characterization of Plasmodium falciparum isolated from the Amazon region of Brazil: evidence for quinine resistance. Am J Trop Med Hyg 1998, 58:630-637.

38. Rogers WO, Sem R, Tero T, Chim P, Lim P, Muth S, Socheat D, Ariey F, Wongsrichanalai $C$ : Failure of artesunate-mefloquine combination therapy for uncomplicated Plasmodium falciparum malaria in southern Cambodia. Malar J 2009, 8:10.

39. Lim P, Alker AP, Khim N, Shah NK, Incardona S, Doung S, Yi P, Bouth DM, Bouchier C, Puijalon OM, Meshnick SR, Wongsrichanalai C, Fandeur T, LeBras J, Ringwald P, Ariey F: Pfmdr1 copy number and arteminisin derivatives combination therapy failure in falciparum malaria in Cambodia. Malar J 2009, 8:11-18.

40. Wilson CM, Volkman SK, Thaithong S, Martin RK, Kyle DE, Milhous WK, Wirth DF: Amplification of pfmdr 1 associated with mefloquine and halofantrine resistance in Plasmodium falciparum from Thailand. Mol Biochem Parasitol 1993, 57:151-160.

41. Cowman AF, Karcz SR, Glalatis D, Culvenor JG: A P-glycoprotein homologue of Plasmodium falciparum is localized on the digestive vacuole. J Cell Biol 1991, 113:1033-1042.

42. Chen N, Kyle DE, Pasay C, Fowler EV, Baker J, Peters JM, Cheng Q: pfcrt Allelic types with two novel amino acid mutations in chloroquineresistant Plasmodium falciparum isolates from the Philippines. Antimicrob Agents Chemother 2003, 47:3500-3505.

43. Cooper RA, Ferdig MT, Su XZ, Ursos LM, Mu J, Nomura T, Fujioka H, Fidock DA, Roepe PD, Wellems TE: Alternative mutations at position 76 of the vacuolar transmembrane protein PfCRT are associated with chloroquine resistance and unique stereospecific quinine and quinidine responses in Plasmodium falciparum. Mol Pharmacol 2002, 61:35-42.

44. Johnson DJ, Fidock DA, Mungthin M, Lakshmanan V, Sidhu AB, Bray PG, Ward SA: Evidence for a central role for PfCRT in conferring Plasmodium falciparum resistance to diverse antimalarial agents. Mol Cell 2004 15:867-877.

doi:10.1186/1475-2875-10-42

Cite this article as: Chaijaroenkul et al:: Sequence and gene expression of chloroquine resistance transporter (pfcrt) in the association of in vitro drugs resistance of Plasmodium falciparum. Malaria Journal 2011 10:42.

\section{Submit your next manuscript to BioMed Central and take full advantage of:}

- Convenient online submission

- Thorough peer review

- No space constraints or color figure charges

- Immediate publication on acceptance

- Inclusion in PubMed, CAS, Scopus and Google Scholar

- Research which is freely available for redistribution

Submit your manuscript at www.biomedcentral.com/submit
C Biomed Central 